\title{
FOOD CONSUMPTION AMONG HEALTHY AND OVERWEIGHT ADOLESCENTS
}

\author{
Mariana Vilela Vieira1, Ieda Regina Lopes Del Ciampo², Luiz Antonio Del Ciampo³
}

\begin{abstract}
Objective: to know the food intake of eutrophic and overweight adolescents. Methods: casecontrol study that analyzed the food intake and habits of adolescents with normal weight and overweight, matched for age and sex, using a food frequency questionnaire and food diaries for 3 days, compared with the Food Guide for the Brazilian Population and analyzed by the software Virtual Nutri. Results: Mean body mass index (BMI) and percent body fat were 29.5 and 49.4 for the overweight group and $21.0 \%$ and $29.1 \%$ for the normal group, respectively $(p<0.01)$. Among normal individuals the average daily intake of calories was 1915.5 while overweight adolescents consumed 1761.8 calories. Most adolescents ate the three main meals: breakfast $(86 \%)$, lunch $(98,9 \%)$ and dinner $(96.8 \%)$. For eutrophic teenagers the average percentage of energy consumed was $56.7 \%$ for carbohydrates, $154 \%$ for proteins and $27.9 \%$ for lipids, while the overweight group consumed $52.7 \%, 17.1 \%$ and $30.2 \%$, respectively. Conclusions: the study showed that both groups of adolescents consume the same types and similar amounts of foods, except when considering the group of cereals, roots and tubers whose consumption was higher among eutrophic adolescents $(p<0.01)$.
\end{abstract}

Key words: adolescent, food consumption, feeding behavior, obesity.

\section{INTRODUCTION}

Adolescence is a phase of physical, emotional, cognitive and social transformations characterized by increased nutritional requirements, with the reinforcement of healthy eating habits being of fundamental importance to guarantee full growth potential, development and the prevention of future diseases. This is a critical period for the development of activities and behaviors related to diet, physical activity and risk behaviors, especially regarding the personality, when the great physical changes occurring in adolescents lead them to deeply value their body image and self-esteem, a fact that often affects their eating habits ${ }^{1,2}$.

Among various factors related to eating habits, the internationalization of eating practices has recently gained emphasis, favoring changes represented by the incorporation of new foods, preferences, and ways to buy, prepare and consume food ${ }^{3}$.

Few and isolated population-based studies are available in Brazil about the eating habits of adolescents. Levy-Costa et al. ${ }^{4}$, when analyzing the home availability of foods in Brazil according to the main database of the Family Budget Research (FBR) 2002-2003, observed excessive sugar consumption and an insufficient presence of fruits and vegetables in the diet. Troiano et al. ${ }^{5}$ reported that the mean percentage of energy from total and saturated fats has decreased compared to the 1970 consumption but has remained above recommendations, with $12.2 \%$ consisting of saturated fat.

In study of the frequency of fat consumption and of the factors associated with fat and fiber consumption among adolescents aged 10 to 12

1 Master's degree in Children's and Adolescents' Health. Departamento de Puericultura e Pediatria da Faculdade de Medicina de Ribeirão Preto da Universidade de São Paulo.

2 Doctor, Assistant Physician. Departamento de Puericultura e Pediatria da Faculdade de Medicina de Ribeirão Preto da Universidade de São Paulo.

3 Professor Doctor. Departamento de Puericultura e Pediatria da Faculdade de Medicina de Ribeirão Preto da Universidade de São Paulo.

There is no conflict of interest.

Corresponding author: delciamp@fmrp.usp.br

Suggested citation: Vieira MV, Del Ciampo IRL, Del Ciampo LA. Food consumption among healthy and overweight adolescents, Journal of Human Growth and Development, 24(2):157-162

Manuscript submitted Aug 01 2013, accepted for publication Dec 282013. 
years in the city of Pelotas (RS), Neutzling et al. ${ }^{1}$ detected the consumption of a fiber-poor diet among $83.9 \%$ of them and of a fat-rich diet among $36.6 \%$, with differences between socioeconomic levels.

The interest in investigating eating behavior is based on the possibility of increasing the effectiveness of nutritional interventions. The assumption is that, as the determinants of eating behavior become better known, there is a greater possibility of success and a more marked impact of actions promoting healthy eating practices ${ }^{6}$.

The objective of the present study was to analyze the food consumption of healthy and overweight adolescent students in the city of Ribeirão Preto (SP).

\section{METHODS}

This was a case-control study which analyzed, according to nutritional status, the eating habits and food consumption of adolescents aged 14 to 19 years enrolled in two state schools in the West region of the city of Ribeirão Preto (SP). Anthropometric evaluation was performed in a first stage in order to identify individuals with excess weight. Adolescents with chronic diseases that compromise the nutritional status and one pregnant girl were excluded. After determination of nutritional status by means of the body mass index (BMI), the adolescents were divided into two groups: one consisting of students diagnosed as overweight and obese and a control group with the same number of students of normal nutritional status matched for sex and age. The second stage of the study consisted of an individual interview during which food frequency questionnaires validated for adolescents were applied ${ }^{7}$ and a 3-day food record was filled out. The semi-quantitative food frequency questionnaire validated for adolescents consists of 76 food items divided into nine groups: 1) sweets, snacks and treats; 2) salty foods and preparations; 3 ) milk and dairy products; 4) cereals, breads and tubercles; 5) vegetables and legumes; 6) fruit; 7) meat and eggs; 8) beans; 9) drinks. Each adolescent chose one of the seven options of frequency of consumption: never, less than once a month; one to three times a month; once a week; two to four times a week; once a day; two or more times a day. A food photo album was used to help them provide the correct information about the size of the portions reported. Additional information was obtained from the three-day food record, with two days being week days and one during the weekend. The adolescent recorded the foods consumed throughout the day both inside and outside the home. Specific guidelines were provided before adolescents filled out the food record about the information to be reported and a food photo album was used to help with the size of the utensils and of home measurements.

All anthropometric measurements were obtained according to standardized techniques using a Plenna ${ }^{\circledR}$ digital electronic scale, Acqua model, with a maximum capacity of $150 \mathrm{~kg}$ and minimum graduation of $100 \mathrm{~g}$ for the measurement of weight, and an Alturaexata ${ }^{\circledR}$ stadiometer with a $\mathrm{cm}$ scale and $1 \mathrm{~mm}$ precision for the measurement of height. Weight and height data were inserted into the EpiInfo software version 3.3.2 for the generation of a data bank and for the calculation of BMI according to the formula: $B M I=$ weight $(\mathrm{kg}) /$ height $^{2}(\mathrm{~m})$. The results were plotted on the BMI curve per age which defined the classification of nutritional status $^{8}$.

For the qualitative analysis of the diet, the food groups were compared to those recommended by the Eating Guide for the Brazilian Population ${ }^{9}$ directed at the Brazilian population older than 2 years. Virtual Nutri software ${ }^{10}$ was used to calculate the nutritional value of the foods consumed and recorded during the three days. The anthropometric data obtained were used to estimate body fat using the equations of Slaughter et al ${ }^{11}$, recommended for individuals aged 8 to 17 years. Records of consumption of less than $500 \mathrm{kcal}$ or of more than $5000 \mathrm{kcal}$ were not considered for the analysis of calorie intake since they may be under- or overestimated, without reflecting reality ${ }^{5}$. Regarding food intake, we calculated the total values and the adequacy of macro- and micronutrients according to the recommendations of the Dietary Reference Intake $(D R I)^{13}$. The association between variables was determined using ANOVA, the non-parametric Wilcoxon test and a mixed effect model. The level of significance was set at 0.05 for all analyses.

The study was approved by the Research Ethics Committee of the University Hospital, Faculty of Medicine of Ribeirão Preto, USP, and all subjects gave written informed consent to participate.

\section{RESULTS}

All 521 students enrolled in 2009 were invited and 435 of them (83.5\%) accepted to participate in the study. Anthropometric evaluation based on BMI identified $36(8.3 \%)$ overweight adolescents and 42 (9.7\%) obese adolescents, who represented the study group. A control group of 78 healthy students matched for sex and age was also included. After the beginning of the second phase of the study, however, 25 subjects dropped out of the study and an adolescent girl who was pregnant at the time of physical evaluation was also excluded, resulting in a total of 135 adolescents who effectively participated in all stages of the study. Thus, the groups consisted of $56(43 \%)$ adolescents with excess weight and $74(57 \%)$ healthy adolescents. Mean age was 196.8 months ( $S D=11$ months), i.e., approximately 16 years and 5 months, and both groups had a greater participation of girls, as can be seen in Table 1.

The distribution of BMI and percent body fat is presented in Table 2. The food frequency questionnaire represents a panorama of the 
Table 1: Distribution of the students by sex and nutritional status. Ribeirão Preto, 2009

\begin{tabular}{lccccr} 
& \multicolumn{2}{c}{ Excess weight } & \multicolumn{2}{c}{ Eutrophy } & total \\
& $\mathbf{n}$ & \% & n & \% & 49 \\
Males & 24 & 42.9 & 25 & 33.8 & 81 \\
Females & 32 & 57.1 & 49 & 66.2 & 130 \\
Total & 56 & 100.0 & 74 & 100.0 &
\end{tabular}

Table 2: Distribution of BMI and body fat according to group. Ribeirão Preto, 2009

\begin{tabular}{cccccc} 
Variables & \multicolumn{4}{c}{ Excess weight } & \multicolumn{2}{c}{ Eutrophy } \\
& Mean (sd) & min - $\max$ & Mean (sd) & min - max & p * \\
BMI & $29.5(4.2)$ & $24.3-43.5$ & $21.0(1.8)$ & $17.5-24.6$ & \\
\% body fat & $49.4(12.6)$ & $17.9-85.12$ & $29.1(9.1)$ & $10.2-52.29$ & $<0.01$ \\
BMI = body mass índex Min = minimum $\quad$ Max = maximum & $*$ ANOVA
\end{tabular}

habitual diet of adolescents and, on the basis of the mean daily portions consumed, permitted the observation of the foods most frequently consumed by the subjects in the two groups, as can be observed in Table 3.
With the three-day food record it was also possible to determine the distribution of the meals during the day. Most of the adolescents ate the three main meals, i.e., breakfast $(86 \%)$, lunch $(98.9 \%)$ and supper (96.8\%). After analysis of the

Table 3: Mean consumption of daily portions obtained with the food frequency questionnaire. Ribeirão Preto, 2009

$\begin{array}{lccc}\text { Food groups } & \begin{array}{c}\text { Excess weight } \\ \text { mean }\end{array} & \begin{array}{c}\text { Eutrophy } \\ \text { mean }\end{array} & \text { p* } \\ \text { Cereals, tubercles, roots } & 4.46 & 5.48 & <0.01 \\ \text { Fruits } & 2.26 & 2.44 & 0.71 \\ \text { Legumes and vegetables } & 3.08 & 3.10 & 0.61 \\ \text { Beans } & 1.77 & 2.12 & 0.14 \\ \text { Milk and dairy products } & 1.75 & 1.93 & 0.22 \\ \text { Meat, fish, eggs } & 2.57 & 2.4 & 0.92 \\ \text { Sweets } & 4.28 & 4.79 & 0.15 \\ \text { Fat } & 1.79 & 1.88 & 0.31\end{array}$

* Wilcoxon

three records using the Virtual Nutri software, it was possible to determine the mean intake of each nutrient according to nutritional status, as described in Table 4.

Table 4: Dietary nutrients according to nutritional status. Ribeirão Preto, 2009

\begin{tabular}{|c|c|c|c|c|c|}
\hline \multirow[b]{2}{*}{ nutrient } & \multicolumn{2}{|c|}{ Excess weight } & \multicolumn{2}{|c|}{ Eutrophy } & \multirow[t]{2}{*}{ p* } \\
\hline & quantity & $\%$ of diet & quantity & $\%$ of diet & \\
\hline Energy (kcal) & 1761.8 & & 1915.5 & & 0.48 \\
\hline Carbohydrate (g) & 230.4 & 52.7 & 270.0 & 56.7 & 0.10 \\
\hline Protein (g) & 74.8 & 17.1 & 73.6 & 15.4 & 0.98 \\
\hline Lipids (g) & 58.8 & 30.2 & 59.1 & 27.9 & 0.92 \\
\hline total & & 100 & & 100 & \\
\hline
\end{tabular}

* ANOVA

\section{DISCUSSION}

The prevalence of excess weight observed in the present study was $18 \%$ ( $8.3 \%$ for males and $11 \%$ for females). Recent data from the Brazilian Institute of Geography and Statistics have shown that prevalence of excess weight has increased in all age ranges, socioeconomic classes and regions of the country. Specifically among adolescents aged 10 to 19 years, overweight has reached $21.7 \%$ of boys and $19.4 \%$ of girls, while obesity has reached prevalences of $5.9 \%$ and $4 \%$, respectively ${ }^{14}$.

The mean percentage of body fat for healthy adolescents was $29.1 \%$, with no considerable differences between sexes. A source of concern detected in the present study was that $95.2 \%$ of the girls and $47.6 \%$ of the boys in the healthy group showed a body fat percentage above normal limits ${ }^{15}$. On the other 
hand, $11 \%$ of the adolescents with excess weight had a body fat of less than $20 \%$, representing high weight due to excess muscle mass and not excess fat mass.

Statistical analysis by ANOVA showed that there was an association between fat percent and nutritional status ( $p<0.01$ ), with a difference between the healthy group and the group with excess weight. Energy intake did not differ significantly between the two groups. In addition, the healthy group showed higher calorie consumption than the groups with excess weight. The most probable explanation would be that students with excess weight under-reported their real consumption either because they did not feel comfortable in describing their diet in detail, knowing that it contained faults, or because they were not fully aware of the quantity of food ingested, as a consequence of a mechanical way of eating.

Similar results were obtained by Manios et al $^{16}$ in a study of 12 - and 13-year-old adolescents in which energy consumption was evaluated by means of a 24-hour recall for three consecutive days. The adolescents with excess weight did not show a difference in energy or macronutrient consumption. In addition, overweight students had a lower calorie intake than healthy students. In contrast, Santos et al.17, in a study of 96 adolescents with a mean age of 16 years, compared intake evaluated by means of a threeday food record to basal metabolic rate and observed that $64.6 \%$ of the interviewees undernotified their food consumption, with obese subjects showing a five-fold higher chance of under-notifying their energy intake than the participants with normal weight. The authors also reported that the under-notifiers presented lower rates of carbohydrate, total and saturated fat and cholesterol intake, showing that, in theory, their eating habits were closer to the eating directives.

Although the literature does not present studies about the consumption of cereals, roots and tubers, the significant difference found in this study could be due to underreporting in the food group predominantly carbohydrates, which popularly believed to be more related to being overweight.

Rice and beans were the foods most consumed among all adolescents even when divided into groups. The mean consumption of beans was greater than the amount recommended by Food Guide for the Brazilian Population in both groups. This result is positive and should continue to be stimulated since beans are a characteristic of the eating habits of Brazilians ${ }^{18}$, in addition to being a food of good nutritional value representing an important source of iron and protein for lowincome adolescents ${ }^{19,20}$.

A worrisome result observed was the presence of "hard candy" among the foods most consumed both in general and by each group. Healthy subjects reported a consumption of 1.7 daily portions of "hard candy", while the students with excess weight reported an intake of 1.6 daily portions. The portion of the hard candy item described in the food frequency questionnaire corresponds to 2 units. The calorie intake calculated corresponds to $59 \mathrm{kcal}$ for 1.7 daily portions, and to $56 \mathrm{kcal}$ for 1.6 portions. Considering cumulative consumption, intake of hard candy may contribute approximately $400 \mathrm{kcal}$ over one week and $1700 \mathrm{kcal}$ over one month, with the calorie source being only simple sugar.

Sugar was consumed at a higher frequency among healthy subjects ( 1.2 daily portions) than among subjects with excess weight (1.1 daily portions). It should be pointed out that the sugar considered here is that purposely added by the adolescent. For a complete evaluation of sugar intake it is necessary to also consider the intake of sweetened ready-made drinks and remaining sweet preparations.

According to Berkey et al. ${ }^{21}$, it can be seen that excess consumption of milk and fruit juices may also contribute to elevated energy intake, but these drinks have a more adequate nutritional composition superior to that of soft drinks, since the latter provide a low micronutrient content and a high calorie content. In the United States, the intake of nutrient-poor foods is believed to represent more than $30 \%$ of the daily intake. Among major foods participating in this proportion are soft drinks, sucking candy, added sugar, and desserts $^{22}$. In Rio de Janeiro, in a study of 387 adolescents aged 12 to 18 years, Andrade et al. ${ }^{23}$ observed that the high energy density foods that most contributed to total energy consumption were sugar, french fries and soft drinks. Dalla Costa et al. $^{24}$ reported that, in the sugar and sweets group, sugar was the food most consumed, with daily intake reported by $78.2 \%$ of the interviewees, followed by hard candy and sweets (59.5\%) and chocolate drinks (40.7\%).

Intake above the limit was also observed in investigations on young people in different countries. A study conducted on Danish adolescents aged 14 to 19 years, $75 \%$ of the subjects interviewed were found to consume addition sugars above the $10 \%$ limit recommended by Nordic countries for this nutritional component ${ }^{25}$. Also in Spain it was observed that sugars corresponded to approximately $16 \%$ of the total energy consumed by adolescents ${ }^{26}$.

Even if we consider only direct sources of fat, the two groups showed a consumption exceeding the portions recommended by the Guide for the Brazilian Population. The individuals with excess weight exceeded by $79 \%$ the quantity of daily portions recommended and the healthy individuals exceeded it by $88 \%$. Regarding the caloric distribution of lipids, the adolescents with excess weight exceeded the recommendation, consuming $30.2 \%$ of the calories in the form of fats. The DRI suggest a distribution differing from the Guide, permitting an intake of up to $35 \%$ of the total calories, a value respected by the two groups ${ }^{13}$.

Regarding the quantity obtained in the daily records of lipids, the recommendation is that the lowest possible level should be obtained for cholesterol and saturated fats in a nutritionally 
adequate diet, although some authors propose that the intake of saturated fats should not exceed $10 \%$ of the caloric value of the diet and that the consumption of cholesterol should not exceed 300 $\mathrm{mg} /$ day $^{27}$. Data about the food consumption of North American individuals aged 2 to 19 years showed that the mean percentage of fat in the diet of young people was $33.5 \%$ of the caloric value, with $12.2 \%$ originating from saturated fatty acids, with a higher value being detected among non-Hispanic blacks ${ }^{28}$. It was also observed that saturated fats contributed $11.6 \%$ of the caloric value among adolescents aged 12 to 15 years, and $12.8 \%$ among children aged 6 to 8 years. The same study showed that, in the 16 to 19 year age range, the monounsaturated fats contributed $12.7 \%$ of the energy values, the polyunsaturated fats contributed $6.8 \%$, and the mean intake of cholesterol was $293 \mathrm{mg}^{6}$. Thirty-four percent of the caloric intake of Danish adolescents aged 14 to 19 years originated from lipids. In contrast, in Sweden several dietary studies showed a change in the diet of individuals aged 14 to 17 years. The caloric contribution of lipids decreased from $44 \%$ in 1967 to $33 \%$ in 1993, a fact explained by the increased consumption of cereals and of skim milk. However, the intake of saturated fats did not change, accounting for $15 / 5$ of the calories consumed ${ }^{26}$.

In Brazil, Levy-Costa et al. ${ }^{4}$ reported that the dairy calories from fats grow proportionally to the increase of income, with this increase being more intense for saturated fats. According to these authors, the calorie distribution in lipids in the Southeast region, where Ribeirão Preto is located, corresponds to $30.2 \%$ of the calories from lipids, $9.3 \%$ from saturated lipids, $9.8 \%$ from monounsaturated lipids and $7.9 \%$ from polyunsaturated lipids. It can be seen that saturated lipid intake is higher than FBR data both in students with excess weight and in healthy students. On the other hand, the intake of monounsaturated and polyunsaturated fats observed in the present study was lower than that reported in the literature. In a study of São Paulo adolescents, Garcia et al ${ }^{29}$ observed a mean $31.3 \%$ participation of fats in their diet, with

\section{REFERENCES}

1. Neutzling, MB, Araujo, CLP, Vieira, MFA. Hallal, PC. Freqüência de consumo de dietas ricas em gordura e pobres em fibras entre adolescentes. Rev Saúde Pública. 2007;41(3):336-42.

2. Toral N, Slater B. Abordagem do modelo transteórico no comportamento alimentar. Cien Saúde Coletiva. 2007;12(6):1641-50.

3. Carmo MB, Toral N, Silva MV, Slater B. Consumo de doces, refrigerantes e bebidas com adição de açúcar entre adolescentes da rede pública de ensino de Piracicaba, São Paulo. Rev Bras Epidemiol. 2006;9(1):121-30.

4. Levy-Costa RB, Sichieri R, Pontes NS, Monteiro CA. Disponibilidade domiciliar de alimentos no
$53.3 \%$ of the boys and $41 \%$ of the girls showing a high consumption of cholesterol.

We may raise the hypothesis that the omission of breakfast $(14 \%)$ and of morning (54.8\%) and afternoon (16.1\%) snacks contributed to the low intake of fruits and milk and dairy products, contributing to a low intake of fibers, vitamins and minerals. According to Nicklas et al. ${ }^{30}$, over the last 25 years, eating breakfast is being reduced among North Americans. Another possibility would be the exchange of milk and dairy products and fruits in the intermediate snacks with foods belonging to the group of sweets and fats. The fact that $54.8 \%$ of the adolescents do not take a morning snack may be attributed to the fact that the school offers a snack similar to a full lunch.

The bias of the nature of the research should also be considered since in cross-sectional studies overweight individuals may restrict food consumption in order to lose weight, stating that they consume a reduced amount of energy when they are interviewed.

Although the number of participants in the present study was small, the strong points of this investigation are the exploration of information regarding the eating habits of an important age range of the Brazilian population, i.e., the adolescents.

Even with the adolescent group classified overweight have reported daily intake of greater amount of total calories and sugars, no statistical differences were observed between the groups, which occurred only when compared to food intake in the group of cereals, tubercles and roots $(p<0.01)$.

Dietary intake of the two groups of adolescents studied showed that the cultural habit of eating rice and beans still remains. Despite the possible underreporting by overweight adolescent it can be concluded that the diet of these individuals and also those considered eutrophic was unsuitable for the age group. The excess of simple sugar and saturated fat, combined with low intake of cereals, fruits and milk leads to the need to implement effective public policies for adequate food consumption by adolescents.

Brasil: distribuição e evolução (1974-2003). Rev Saúde Pública. 2005;39(4):530-40.

5. Troiano RP, Briefel RR, Carroll MD, Bialostosky $\mathrm{K}$. Energy and fat intakes of children and adolescents in the United States: data from the National Health and Nutrition Examination Surveys. Am J Clin Nutr 2000, 72 (Suppl):1343S-53S.

6. Ni Mhurchu C, Margetts BM, Speller VM. Applying the stages-of-change model to dietary change. Nutr Rev 1997;55:10-6.

7. Slater B, Philippi ST, Fisberg RM, Latorre MRDO. Validation of a semi-quantitative adolescent food frequency questionnaire applied at a public school in São Paulo, Brazil. Eur J Clin Nutr 2003;57:629-35. 
8. de Onis, Onyango AW, Borghi E, Siyam A, Nishida C, Siekmann J. Development of a WHO growth reference for school-aged children and adolescents. Bul World Health Org 2007;85:660-7. Doi: 10.2471/BLT. 07.043497.

9. Mattos AP, Brasil ALD, Mello ED. Manual de Orientação: alimentação do lactente, alimentação do pré-escolar, alimentação do escolar, alimentação do adolescente, alimentação na escola. Sociedade Brasileira de Pediatria. Departamento de Nutrologia, São Paulo, 2006. P.32-38.

10. Philippi ST, Szarfarc SC, Latterza AR. Virtual Nutri [software]. Versão 1.0 for Windows. Departamento de Nutrição/Faculdade de Saúde Pública/ Universidade de São Paulo, 1996.

11. Slaughter MH, Lohman TG, Boileau RA, Horswill CAl. Skinfold Equations for Estimation of Body Fatness in Children and Youth. Hum Biol 60(5):709-723.

12. Feskanich D, Rockett HRH, Colditz GA. Modifying the Healthy Eating Index to assess diet quality in children and adolescents. J Am Diet Assoc 2004;104(9):1375-83.

13. Institute of Medicine. Dietary reference intakes for energy, carbohydrate, fiber, fatty acids, cholesterol, protein and amino acids. Food and Nutrition Board. Washington, DC: National Academy Press;2002. P.107-540.

14. IBGE - INSTITUTO BRASILEIRO DE GEOGRAFIA E ESTATÍSTICA. Pesquisa Nacional por Amostra de Domicílios 2009 - Síntese dos indicadores. Rio de Janeiro: IBGE, 2010. p.135-163.

15. Vieira VCR, Priore SE, Ribeiro SMR, Franceschini SCC. Alterações no padrão alimentar de adolescentes com adequação pondero-estatural e elevado percentual de gordura corporal. Rev Bras Saúde Matern Infantil 2005;5(1):93-102.

16. Manios $Y$, Kolotourou M, Moschonis G, Sur $H$. Macronutrient, physical activity, serum lipids and increased body weight in primary schoolchildren in Istanbul. Pediatr Int 2005;47:159-166.

17. Santos LC, Pascoal MN, Fisberg M, Cintra IPI. Misreporting of dietary energy intake in adolescents. J Pediatr (Rio J)2010;86:400-4. DOI.0021-7557/10/86-05/400

18. Philippi ST, Latterza AR, Cruz ATR, Ribeiro LC. Pirâmide alimentar adaptada: guia para escolha dos alimentos. Rev Nutr1999;12:65-80.
19. Philippi ST. Pirâmide dos alimentos. Fundamentos básicos da nutrição. In: Alimentação saudável e a pirâmide dos alimentos. Barueri: Manole, 2008. P.1-29.

20. Estima CCP, Costa RS, Sichieri R, Pereira RA, Veiga GV. Meal consumption patterns and anthropometric measurements in adolescents from low socioeconomic neighborhood in the metropolitan area of Rio de Janeiro, Brazil. Appetite, v.52, p.735-736, 2009. PMid:19501773. http://dx.doi.org/10.1016/j. appet. 2009.03.017

21. Berkley CS, Rockett HR, Field AE, Gillman MWI, Colditz GA. Sugar-added beverages and adolescent weight change. Obes Res 2004;12:778-88.

22. Muñoz KA, Krebs-Smith SM, Ballard-Barbash $\mathrm{R}$, Cleveland LE. Food intakes of US children and adolescents compared with recommendations. Pediatrics 1997;100:323-9.

23. Andrade RG, Pereira RA, Sichieri R. Consumo alimentar de adolescentes com e sem sobrepeso do Município do Rio de Janeiro. Cad Saúde Pública 2003;19:1485-95.

24. Dalla Costa MC, Cordoni Junior L, Matsuo T. Hábito alimentar de escolares adolescentes de um município do oeste do Paraná, Brazil. Rev Nutr 2007;20(5):461-71.

25. Samuelson G. Dietary habits and nutritional status in adolescents over Europe. An overview of current studies in the Nordic countries. Eur J Clin Nutr 2000;54:S21-S28.

26. Cruz JA. Dietary habits and nutritional status in adolescents over Europe - Southern Europe. Eur J Clin Nutr 2000; 54 (suppl.1): S29-S35.

27. WHO. Diet, nutrition and the prevention of chronic diseases. Technical Report Series 916. Geneva; 2003.

28. Goodwin DK, Knoll LL, Eddy JM, Fitzhugh EC. Sociodemographic correlates of overall quality intake of US adolescents. Nutr Res 2006;26:105-10. doi:10.1016/j. nutres. 2006. 02.004 .

29. Garcia CB, Gambardella AMD, Frutuoso MFP. Estado nutricional e consumo alimentar de adolescentes de um centro de juventude da cidade de São Paulo. Rev Nutr 2003; 16(1): 41-50.

30. Nicklas TA, O'neil C, Myers L. The importance of breakfast consumption to nutrition children, adolescents, and young adults. Nutr Today 2004;39:30-9. 